\title{
Prison health in Nigeria: A sociological discourse
}

\author{
Agunbiade Ojo Melvin \\ Department of Sociology/Anthropology, Obafemi Awolowo University, Ile-lfe, Nigeria. \\ Accepted 10 December, 2010
}

\begin{abstract}
In many developing countries including Nigeria, prison conditions are far from being humane, and prison health is yet to be seen as a profitable social project. This is often displayed in the various forms of social interactions obtainable among prisoners, prison staff and the larger social system. Prisons in Nigeria over the past years have been in deplorable conditions with increase in disease burden among inmates. The worrisome part is not the governments' willingness to join the global drive towards realising access to health care service, but the slowness in attitude in addressing the health needs of prisoners; yet prison health remains paramount. In the light of the above background, the paper therefore, attempts a sociological discourse of prison health in Nigeria within the context of the dynamics of social structures on prison health as well as suggest plausible strategy through which optimum prison health in Nigeria could be realised.
\end{abstract}

Key words: Inmates, punishment, prison staff, prison health, prison condition.

\section{INTRODUCTION}

Seven years into the new millennium, health for all in Nigeria and many African nations has remained mirage. Recent assessment of African Health systems indicates a gloomy picture of weakness in performance (African Regional Health Report, 2006). The inability to provide quality and equitable access to health care services through much reliance on western health care framework have further widening the existing health inequalities in many African countries and the Nigerian populace in particular. This scenario has also the poor and the rich, urban and rural dwellers, inmates and the "free" at different axis of the production spectrum of health care delivery in Nigeria. A good example of this unfavourable equation becomes obvious when the health of special groups like the prisoners is critically examined (Health in African Prisons, 1999). Evidence has linked major determinants of health in modern populations to socioeconomic, political and cultural factors and as such inequalities in health have remained problematic across cultures, socio-economic class, gender or ethnicity
(Bambra et al., 2005). In the social sequence of events, prisoners are most times from the poorest sectors of the society, and suffer more from inequitable access to health care services. This experience also exacerbates existing health problems of inmates (de viggiani, 2007). Hence, the current drive towards realising the health related millennium development goals requires more forceful drive from the Nigerian government. Health is political and the power exercised over it is part of the wider economic, social and political system (Bambra1, et al., 2005). Thus, achieving both qualitative and quantitative health among special groups like inmates may be far from realisation going by the slow attitude of prison administrators and the government in particular in addressing the health needs of prisoners. Hence, this paper attempts a sociological discourse of prison health within the social context producing it. This was done by discussing prison health in Nigeria as a social product. The paper further suggest plausible model on which optimum prison health in Nigeria could be realised. 


\section{The philosophy of punishment and the emergency of prison in Nigeria}

Jail which is also commonly called Prison in many countries represents the oldest penal institution. The evolution of this penal institution and its modern form could be traced to the philosophy of punishment. By definition, punishment involves the infliction of pain (Oxford Advanced Learners Dictionary, 2000). Consensus on the ideal of punishment has not been achieved among philosophers; yet two major schools of thought have emerged in this regard. One thought is that inflicting pain as punishment is fundamentally different from inflicting pain on innocents, and thus is not inherently wrong. The other is the belief that punishment is a wrong that can be justified only if it results in a "greater good" (Murphy, 1995). These two views have been described as the retributive and utilitarian approaches and have dominated and facilitated the wide acceptance of Prison as a system of social control (Durham, 1994). As a social agency of criminal justice administration, prison has two basic fundamental functional roles which are in terms of incarcerating convicts as well as providing custodial care for those under trials and in detention. On the prisoners, critics have argued the dysfunctional nature of prisons as a social institution that attacks the soul, acts on the thoughts, the will, and the inclinations of the prisoners (Howe, 1994).

Historically, imprisonment as a mode of punishment could be traced to the $16^{\text {th }}$ century, but became widely spread only in the $19^{\text {th }}$ century. Before then the few prisons that existed were used mainly to hold those destined for some other punishment such as execution or to contain people unable to pay their debts (Foucault, 1977). This idea emanated from the conservatism and Liberalism philosophy of punishment. The conservatism paradigm views human beings as possessors of freewill, ability to make rational choices and expects logical results of their choices. In contrast, the liberal ideology holds that human behaviour is influenced by upbringing, affluence or poverty, education and life experiences in general. The former perspective emphasis deterrence and incapacitation as conditions to discourage from indulging in deviant acts and motivates conformity to socially acceptable forms of behaviour. The liberal philosophy encourages rehabilitation and reform. This is influenced by the assumption that prison should be able to change the individual rather than destruction. This assumption has been attacked by the radical paradigms as they view prison as instruments of the powerful to enslave the powerless. The radical paradigm thus calls for abolishment of prison and calls for the reformation of law and equitable access to social means of achieving socially approved goals (Durham, 1994). So far, both conservative and liberal philosophies of imprisonment have greatly influenced the formation and operation of penal system in Nigeria which interestingly was fashioned in line with that of Britain, Nigerian former colonial masters. Modern prison in Nigeria has remained a colonial legacy (Rotimi1982); but the needed reforms to salvage prisoners health in Nigeria requires concerted efforts from all stakeholders especially with fast deteriorating state of prison conditions in Nigeria. As a result issues relating to prison health have not fared better since the general imprisonment philosophies govern the process of becoming an inmate, prison conditions and health as well as the process of regaining freedom.

\section{Theoretical reflections on prison as social sub- system}

In Talcott Parsons analysis of the social system, the penal system is assumed to be functional to the maintenance of social order in a modern society. As such actors within the sub-system (prison) are expected to perform specific roles attached to their positions within the sub-system. Hence, roles are defined within the social structures in which individual actors operate (Parson, 1962). From Parsonian lens, Prison staff and prisoners are actors within a sub-system (prison) in a larger social system. And both actors perform certain roles that are defined by a dominant social ideology that considers the performance of these roles as functional to the larger social system. These roles also changes in relation to the social dynamics found within the prevailing political economy framework and other social forces obtainable in that society. Through institutionalisation, prison staff and prisoners are indoctrinated into various roles determined by the societal and institutional expectations attached to their positions. While one may not deny the influence of behavioural or psychological traits on the staff and prisoners' perception and actual performance of their roles, the social structures (economic, political, and religious, among others) exert pressure on the effectiveness and efficiency or none performance of these role.

Sequel to their entrants into the prison system, both the prison staff and prisoners are indoctrinated into different norms and values that would guide their interactions. As new recruits in the prison system, prisoners are ordered to surrender all that identified them as responsible adults, allocated a prison uniform and number and are addressed only by surname. This course represents the beginning of a 'mortification' process, as their selfconfidence, self-esteem and identity diminishes and feelings of alienation emerges (de Viggiani, 2007). The roles attached to prison staff and prisoners positions are subsequently displayed in the power sharing and creation of social outcomes in prison system. Foucault (1977) in "Discipline and Punish" explored the notion of power in tracing the rise of the prison system in modern society as 
well as the rise of other coercive institutions such as monasteries, the army, mental asylums, and other technologies. In this work ,Foucault exposes how seemingly benign or even reformist institutions such as the modern prison system are technologies that are typical of the modern, painless, friendly, and impersonal coercive tools of the modern world. In fact the success of these technologies stems from their ability to appear unobtrusive and humane.

These prisons, Foucault goes on to explain, are like many institutions in the post 1700th century society that isolate those the society deems abnormal. This isolation seeks to attack the souls of people in order to dominate them similar to how the torture and brutality of pre-1700th century society sought to dominate the physical bodies of prisoners. In Foucault's interpretation, freedom from the pervasive influence of "power" is impossible. Because his conception of "power" exists not just in individual institutions of society like prisons but instead exists in the structure of society and more importantly in peoples thought systems and as such escape from social control is impossible. In his final analysis, issues relating to even the reforms in the prison systems have been co-opted to further the goals of the state and not inmates interests. Instead of a lessening of social control, Foucault sees that the technologies change from the wheels and gallows of the 17th century to the disciplinary society of the 19th century to the emerging "carceral city of the future". In this carceral city, the dispersion of power will be complete. The technologies of control will emanate from all parts of society, "walls, space, institution, rules, and discourse." Foucault's final submission still remains relevant especially in the discourse on the preparedness of the Nigerian prison service towards achieving a humane prison system. Going by the dismal conditions of prisons in the country, only a radical change in both orientation and the necessary political will may salvage the Nigerian prison system. A look at prison health in Nigeria will serve as a pointer to how prisoners are still perceived by the society despite the global drive towards reformatory prison system.

\section{Prison health in Nigeria}

Prisoners when compared to other members of the society are worse off as they often bring a range of health problems to prison; they are also at risk from a number of health problems while in prison (Watson et al., 2004). In a recent review of the literature, Watson et al. (2004) identified a range of health problems common among prisoners were as follows: Mental health; Substance abuse and Communicable diseases. A number of these health related problems have also been confirmed in some Nigerian prisons (Adesanya et al., 1997; Agbahowe et al., 1998).

The general condition of health care delivery in Nigeria has further placed prisoners' health in jeopardy. Again, there are chances that many of the mental health problems may be under diagnosed in Nigeria. Some studies have confirmed the vulnerability and plausibility of prisoners with mental health problems becoming problematic to correctional staff and other prisoners than prisoners without mental health problems (Hilton and Simmons, 200; Hoptman et al., 1999). Such empirical studies are still lacking in the Nigerian context. Studies on mental health issues in Nigerian prisons have become crucial in providing empirical evidence on which prisons reform could be achieved. An appraisal of the mental health policy in Nigeria by Odebiyi (1991) revealed a general poor social attitude from the government and other stakeholders towards the mentally ill. Again those in prisons are worse off as they are left out of the policy. The policy has not lived up to expectations in meeting the challenges of caring for the mentally ill in the populace and that of prisoners who are worse off.

Substance abuse is common among those committed to prisons (Watson et al., 2004). While there have been reports on the psychological conditions of prisoners in Nigeria, there is a dearth of research efforts on substance abuse and control among prisoners in Nigeria. Other forms of substance abused by prisoners in Nigeria have been reported by Adesanya et al. (1997). At the prison level, some prisoner may have become exposed to substance abuse through their interactions with other inmates and where such is not the case, prison staff may at times aid or facilitate the flow of hard drugs to the prisoners. Such attitude may be explained within the culture of corruption that have become like a viral infection in Nigeria. This is further worsened by the poor remuneration package prisons staff enjoys and the inability of the Nigerian prison system to attract qualified and motivated professionals may not have been in the systems' favour.

The prison population is not been left out of the various sexually transmitted diseases as different studies have shown the presence and prevalence of these infections and other communicable diseases in Nigerian prisons. While HIV/AIDS seems to be attracting much attention than other communicable diseases, this does not negate the presence of other infections among the prison population. Empirical evidence on communicable diseases among prison population revealed sexually transmitted infections including HIV/AIDS as the leading disease. An estimate in a study by Potts (2000) indicts the prevalence rate of sexually transmitted infection including HIV/AIDS, to be 20 times greater than that of the general population. Sexually transmitted infections in prison have become global and thus command some level of attention. A study by Okochi et al. (1991) on sexually transmitted infections among prisoners in Agodi, Ibadan, Nigeria revealed that inmates' males and females engage in risky sexual behaviours which may further aggravate the further spread of HIV/AIDS in prisons. 
Another critical communicable disease among prisoners is tuberculosis. Tuberculosis (TB) has been ranked $9^{\text {th }}$ leading global health problem (United Nations Development Programme, 2006). Prisons overcrowding in Nigeria (Enuku, 2001), may have also contributed to the growth of communicable disease among prisoners and prison staff as well.

\section{CONCLUSION}

A more holistic prison reform that is focused on all stakeholders including the prisoners is a necessity in bringing about significant changes in promoting prison health as well as making the Nigerian prison humane within a limited time. In addition, the constitutional rights of the accused need to be reinterpreted in such a way that undue delay and incarcerations of awaiting trialsthat has contributed to prisons overcrowding in Nigeria will be minimised. More judges could be employed even on part-time basis to facilitate quite delivery of judgments (Enuku, 2001). While trying to make prison more humane it should not be at the expense of the larger public interest. At the same time the prison should $b$ geared towards reforming the prisoners to better being for themselves and the larger society. For instance the National Economic Empowerment and Development Strategy started by the Obasanjo administration could be extended to those in prisons especially the youths and the women in incarceration. If properly done quite a number of the prisoners who are mostly from poor economic background will be better after leaving the prison. However, introducing such programme will require a reorientation of the prison staff from what they have been socialized into new norms. More qualified hands need to be recruited into the Nigerian prison service especially in the drive towards professionalism and maintenance of social order. This will affect the quality of staff and interaction outcomes as they relate more often with the prisoners than any other government agency. In the final analysis, alternative to prison such as the parole system, community service may be better options than imprisonment. Alternative measures such as the ones mentioned here when properly designed and implemented within the socio-cultural context of the Nigerian society may be cost effective and functional than the present system.

\section{REFERENCES}

Adesanya A, Ohaeri U, Ogunlesi Adamson A, Odejide A (1997). Psychotic substance abuse among Inmates population of a Nigerian prison population. Drug and Alcohol Dependence, 47:39-44. Retrieved March 11, 2007 from http://www.sciencedirect.com/ science.
Agbahowe SA, Ohaeri JU, Ogunlesi AO, Osahon R (1998). Prevalence of psychiatric morbidity among convicted inmates in a Nigerian prison community. East Afr. Med. J. 75:1. Abstract. Retrieved March 20, 2007 from http://www.ncbi.nlm.nih.gov/entrez/query.fcgi? $\mathrm{CMD}=$ Search\&DB=pubmed.

African Regional Health Report (2006). Retrieved September 11, 2007 http://whqlibdoc.who.int/afro/2006/9290231033_rev_eng.pdf.

Bambra C, Fox D, Scott-Samuel A (2005). Towards a politics of health. Health Promotion International, 20, 2:187-193.Retrieved June 11, 2007 from http://heapro.oxfordjournals.org/cgi/reprint/ 20/2/187.pdf? ijkey=q4dHHNIBv113OsC\&keytype=ref.

De viggiani N (2007). Unhealthy prisons: exploring structural determinants of prison health. Sociol. Health Illness 29(1):115-135. Retrieved March 5, 2007 from http://www.blackwell-snergy.com.

Durham A (1994). Crisis and Reform: Current Issues in American Punishment. Boston: Little, Brown.

Enuku UE (2001). Humanizing the Nigerian Prison through Literacy Education: Echoes from Afar. JCE 52(1):18-22. Retetrieved October 22, 2006 from http://www.nwlincs.org/correctional_ education/ articles/nigerian-prison-enuku.pdf

Foucault M (1977). Discipline and Punish: The Birth of the Prison. Trans. Alan Sheridan. New York: Vintage.

Health in African Prisons (1999). A workshop organised by Penal Reform International: Uganda. Retrieved October 16, 2007 from http://www.penalreform.org/resources/rep-1999-health-africanprisons-en.pdf.

Hilton NZ, Simmons JL (2001). The influence of actuarial risk assessment in clinical judgments and tribunal decisions about mentally disordered offenders in maximum security. Law Human Behav. 25:393-408.

Hoptman MJ, Yates KF, Patalinjug MB, Wack RC, Convict A (1999). Clinical prediction of assaultive behaviour among male psychiatric patients at a maximum-security forensic facility. Psychiatric Services 50:1462-1466. Retrieved January 28, 2007 from http://www. psychiatricservices.psychiatriconline.org/cgi/reprint/50/11/1461.

Howe A (1994). Punish and Critique: Towards a Feminist Analysis of Penalty. London: Routledge.

Murphy J (1995). Punishment and Rehabilitation, 3d ed. Belmont, CA: Wadsworth.

Odebiyi A (1991).Appraisal of the mental health care policy in Nigeria.Ibadan: Development Policy Centre.

Okochi CA, Oladepo O, Ajuwon AJ (1991). Knowledge about AIDS and sexual behaviours of Inmates of Agodi Prison in Ibadan, Nigeria. Int. Q. Community Health Educ. 19(4). Abstract. Retrieved March 2,2007 from http://www.baywood.metapress.com.

Parson T (1951).The Social theories of Talcott Parsons. A critical examination by Black Max. Englewood Cliffs, N.J.Prentice-hall, Inc.

Potts JR (2000). HIV/AIDS in federal prisons: Canada's national response. HIV Prevalence Plus 2(2):1-3.

Rotimi A (1982). Prison administration in Modern Nigeria. Int. J. Comp. Appl. Crim. Justice 9(1):73-83.

Watson R, Stimpton A, Hostick T (2004).Prison health care: A review of literature. Int. J. Nurs. Stud. 41:119-128. Retrieved February 2, 2007 from http://www.sciencedirect.com/science/journal.

United Nations Development Programme (2006). Human development Report. Retrieved March 17, 2007 from http://www.hdr.undp.org/ hdr2006/statistics/indicators/86.html. 